\title{
The Degree to which Private Education Students at Princess Nourah Bint Abdulrahman University have Access to Soft Skills from their Point of View and Educational Body
}

\author{
Saeb Kamel Allala ${ }^{1}$, Ola Mohy Aldeen Abusukkar ${ }^{2}$ \\ Department of Special Education, \\ Faculty of Education Princess Nourah bint Abdulrahman University \\ Saudi Arabia
}

\begin{abstract}
The study aimed at identifying the degree of ownership of special education students in the Department of Special Education, Faculty of Education, Princess Nourah University for soft skills from their point of view and the consideration of the educational body and its relation to some variables (level of study, specialization, teaching experience). The study consisted of (26) faculty members in the Department of Special Education, and the second consisted of (287) female students of the Department of Special Education at different levels and specializations, and the data using the Statistical Package for Social Sciences analysis (SPSS). The results of the statistical analysis of the study data indicated that the total score of students' possession of soft skills according to their point of view was low, except for some of the paragraphs in which the estimate was high. The degree of possession of soft skills from the point of view of faculty members was also low, and the results of the study also indicated that there were differences between the students due to specialization and the level of the school tend to favor the higher level of the study, while there were differences according to the view of the faculty for the higher experience, while the results did not indicate a difference attributed to $R$ faculty members. The study recommended increasing the interest in soft skills for female students in particular, and for female students in general, by including these skills in the study courses and through the various student activities.
\end{abstract}

Keywords-Soft skills; special education students; faculty members; Princess Nourah Bint Abdulrahman University

\section{INTRODUCTION}

The phenomenon of unemployment among young people, especially among graduates of higher education institutions, which is increasing in number every year, is growing. This phenomenon is accompanied by a decline in the ability of public and private institutions to absorb more workers. In response to this phenomenon, many countries reviewed their educational and training systems A new dimension that aims to raise the interest of young students and develop their attitudes. Education is one of the most decisive factors in creating opportunities for young people to lead healthy, productive and responsible lives. Investments in youth education help make them good people.
The vision of the Kingdom of Saudi Arabia 2030 indicates that "one of our commitments education that contributes to the advancement of the economy We will seek to bridge the gap between the outputs of higher education and the requirements of the labor market, develop public education, guide students to appropriate career and career options, This is done only by qualifying university graduates with so-called solid skills and soft skills. Employers prefer the employee who has solid skills as well as soft skills. Solid skills are the specific cognitive and technical skills of each discipline, oft Skills) aspects of speech, good and distinct appearance, and special queens highlighting the applicant for the job among peers [5].

The term "soft skills" has become very frequent in recent times. It refers to "those basic skills that are associated with personality, competencies and positive traits that enhance a person's relationships and functioning. These skills include communicating effectively with others, presenting ideas in a convincing and tactful manner, With conflicts, teamwork, the use of leadership behaviors that characterize his relationships with others, initiative, accept criticism and manage time effectively, work under pressure, affection for others and demonstrate good manners [1,12].

In this research, we will discuss the soft skills, their importance, their definitions and types, and the different studies they have dealt with. We will examine the degree to which the special education department has a selection of soft skills. According to the researchers, this research is the first of its kind - the least.

\section{STUDY QUESTIONS}

This study attempts to answer the following questions, which are focused on the degree of ownership of special education students at Princess Nourah University Soft Skills from their point of view and consideration of the educational body and the questions are:

- What is the degree to which the students of the special education department have a soft skill from their point of view?

- What is the degree of ownership of female students of the Department of Special Education for soft skills 
from the perspective of members of the Education Authority?

- Are there statistically significant differences at the level of $(0,05)$ degree to the degree of possession of students of the Department of Special Education for soft skills from their point of view due to the variable specialization?

- Are there statistically significant differences at the level $(0,05)$ for the degree of possession of female students of the Department of Special Education for soft skills from the point of view of the members of the Education Council due to the variable specialization?

\section{A. Objectives of the Study}

This research aims to identify the degree of ownership of special education students at Princess Nourah University for soft skills from their point of view and the educational body's view. The objectives of the research are as follows:

1) The availability of soft skills in the students of the Department of Special Education / Faculty of Education / University of Nourah bint Abdulrahman.

2) Identify the degree of ownership of soft skills according to the student's specialization in the section (learning difficulties, autism, talent and mental excellence).

3) Recognition of the estimates of faculty members to the degree of soft skills for female students according to the variable of specialization faculty member.

\section{B. Importance of Studying}

The importance of the study is as follows:

1) Theoretical importance: Although the study plans are interested in specialized information (hard skills), they often neglect to give the soft skills they deserve. This study attempts to draw attention to the importance of these skills, and is it available to university students enough to qualify for entry into the labor market by force and form.

2) Practical importance: Proposing a standardized scale for measuring soft skills for female university students. Enrich the Arabic and Saudi Library with research on soft skills.

The results of the study will show the nature of the availability of soft skills and therefore make recommendations to take into account in the study plans and characterization of the decisions of the different courses; and to draw the attention of faculty members to the importance of these skills and the need to include them in the activities of different courses.

\section{Terminology of Study Soft Skills}

Is the personal skills that enable the individual to deal positively with those around him, and know the procedure in this research degrees possessed by students from their point of view and the view of the faculty on the scale that will prepare for this goal, and will cover the following soft skills: Connect and communicate with others, Creative thinking, critical thinking, dialogue skills, teamwork, self-management and interpersonal skills, emotional / emotional intelligence skills, teamwork skills, decision making and problem solving skills.

\section{Students of Special Education Department}

They are students enrolled in the Department of Special Education, Faculty of Education, Princess Nourah University for the academic year 1438-1439.

\section{E. At Different Levels of Study}

Faculty members: They are members of the teaching staff in the special education department at the Faculty of Education, Princess Nourah University from the academic year 1438-1439. The study limits are as follows:

The sample of the study was limited to students of the Special Education Department at the Faculty of Education, Princess Nourah Bint Abdul Rahman University for the academic year 1348-1349 AH

Study tool: Soft skill scale (female students, faculty members) and their psychometric characteristics, which are prepared by researchers.

\section{F. Theoretical Framework and Previous Studies}

When reviewing the theoretical literature, a series of studies was examined, which examined soft skills in general, those that examined soft skills and their impact on recruitment and job acquisition after graduation. The researchers did not find, to their knowledge, any of the studies that examined soft skills Especially in the field of special education, but most of the studies examined the impact of the availability of these skills on success in employment and employment, and perhaps this scarcity in addressing the special education specialization as a humanitarian specialization is increasing demand as it relates to the category of persons with disabilities, Perhaps what s S gives importance to our research and opens up horizons and encourages researchers to methods of this subject, which is relatively recent.

In this paper, we will refer to the most important studies that examined soft skills in various variables. Academic institutions have simply gone beyond thinking about the technical skills required in the labor market to new skills called Soft Skills. These skills are related to social behavior in the workplace. Perhaps the last thing the West is interested in today is what they call "Soft Skills" Which translates to soft or gentle skills, and researcher in this type of skills work in the West easily find it is a values of work urged by Islam and values that govern the relationship of the individual to the group to which he belongs in the work environment, those values that promote the concepts of integration and cooperation and interdependence, For example Ok selfMuasher (God bless the slave Simha if sold Simha if bought) And the love of the other side and transparency (against fraud) and acceptance of the other, these values that the Western world is interested in today in the academic work is one of the fundamentals of work ethics in Islam and is of great importance in academic work is often lacking in our institutions and we are the first (Said, 2011). Soft skills are modern concepts associated with sociology, particularly emotional intelligence, as they are closely related to personal and social traits, as well as to their intrinsic connection to communication and relationships. The author in [12] identified them as traits and abilities that appear in attitudes and behavior rather than knowledge or technical competence. The 
author in [3] identified them as a set of personality traits related to the area of communication with others in a friendly atmosphere.

Collaboration and reflect the employee's sense of wellbeing with the work environment. It is also related to the ability to express oneself and communicate with the digital technology that is required by everyone in our time, such as computer skills, e-mail, social networking, Attractive.

Forbes Middle East and the British Broadcasting Corporation (BBC) reported that Soft Skills is a factor that is no less important than the specialized skills that will qualify the job seeker. For Labor [7] As reported by the BBC .on 14 January 2015 that soft skills have improved productivity and reduced operating costs in Britain by at least 88 billion pounds ( $\$ 130$ billion) a year, as these soft skills complement the hard skills Are related to the knowledge, experience and ability to carry out the tasks specified in the Professional Job Description. Experts speak of the fact that the lack of softness in the labor force leads to negative consequences [1][11].

The skills that were included under the name of soft skills include: communication skills, self-management skills, negotiation / rejection skills, emotional / emotional intelligence skills, teamwork skills, decision making and problem solving skills, creative and critical thinking skills With stress, dialogue skills in the community, a combination of these skills will be selected to be the current research vocabulary. Attention to these skills stems from university graduates in general, as we live in the age of knowledge-based economy. Where the competition between countries depends on the ownership of the workforce of skills consistent with the characteristics of this era, which led to different requirements of the workforce that aspire to the advancement of this economy, and the need for individuals to have skills to enable them to live and work in the society of the age of knowledge, , Effective communication with others depends on technology, and need is increased. To have the skills to solve nonstereotypical problems and to find creative solutions to these problems, all of the above requires the rethinking of the skills that learners need to prepare them for life and work in this age.

The importance of soft skills and the role that educational institutions can play in educating learners is evident in many reports and studies from institutions and study centers. The study by Young Enterprise, which included large institutions, indicated a lack of They are interviewed for the functional skills that come to soft skills within the office and the work environment at the forefront, which led them to search for foreign competencies or establish branches of their institutions Abroad to get out of this problem and find a solution, and the Foundation is due to the lack of efficiency of intensive graduates of educational institutions on academic skills and tests, which reduces the possibility of graduation competencies with the skills required for employment. [7][6]

The importance of care and attention to these skills, which is no less important than the scientific and cognitive skills that compete in universities and colleges in the competition and attention to this aspect of knowledge, while a few universities and colleges to turn to the so-called soft skills, and this research only an attempt to attract Attention to the importance of this type of competencies to be provided in the university graduates, and as one of the objectives of the Department of Special Education in the Faculty of Education at Princess Nourah University, the preparation of qualifications for the care of people with special needs and develop their abilities and energies and investment so as to enable them to merge The positive interaction in the community, and this cannot be achieved as seen researchers only through the possession alumna soft skills that qualify them for integration And this cannot be achieved, as the researchers see only through the possession of the graduate of the soft skills that qualify for integration and positive interaction in society was this research to investigate the availability of these skills in the female students in the section or not.

\section{PREVIOUS StUdies}

The study of [2] aims to identify the role of soft skills in the process of capturing administrative functions in the Gaza Strip by identifying the most important soft skills that affect the process of capturing administrative functions and by identifying the most important soft skills required in the administrative labor market. The researcher used the descriptive analytical method to conduct the study. The researcher used the questionnaire as a main tool in the collection of information. The study population may be from the administrative staff. The questionnaire was distributed to a random sample of 150 employees. The study reached the following results: Statistic The study also found that the dependent variable is affected by the independent variable (networking, anger management, negotiation, etc.). , Crisis management, critical thinking, self-presentation, and professionalism), in a statistically significant and statistically significant manner. The study recommended that job seekers, especially in the field of administrative functions, should develop their soft expertise, the focus is on university specialization or university level only.[10] aims to identify students' perceptions of the importance of soft skills in their education and their employment, and that soft skills play a key role in achieving a successful career through social interactions in society, The researcher used the descriptive method in his study. The study tool was a questionnaire for collecting data, which was distributed to the study sample which reached (188) students specializing in business administration from four universities in Singapore. The results of the study showed that business students in general in Singapore were aware of the importance of soft skills For work And skills that contribute to their academic performance. The most important skills they possessed were teamwork, collaboration, decision making, problem solving, time management, and critical thinking skills. The study showed that other skills needed to be improved further, The study recommended some measures to improve the skills of students, which help improve the horizons of their work from their point of view, in addition to the need of educational institutions to raise awareness among students about the importance of soft skills in research and work [9], which was titled "The Need of Students and Professionals for Soft Skills Training," aimed to emphasize the need to integrate soft skills training programs with the curriculum to highlight the desired 
objectives of these skills and the different teaching methods to be applied. The soft skills training program consists of developing effective communication skills, presentation skills, team management, leadership skills, and focus on personal skills such as teamwork and behavioral skills improvement. The study received feedback from students The study concluded that the importance of effective communication and personal skills in increasing the chances of employment and competition strongly in the work environment, and soft skills programs develop and improve, and that these skills are characterized by the smooth transition of students From his ambition and direction to success as a business tycoon. The study recommended that more effective initiatives be taken to develop students to take into account the soft skills relevant to each discipline.

White's study [13] aimed to demonstrate the importance of soft skills for employers in the recruitment process, showing that $60 \%$ of employers do not employ university graduates and most job applicants due to their lack of soft skills, including communications, Interpersonal skills, and critical thinking.

The study of [8], entitled The Importance of Soft Skills: Teaching beyond Academic Knowledge, aimed at understanding the importance of soft skills in the life of students during undergraduate and postgraduate years. The researcher discusses in this study that soft skills complement solid skills ), Which is a prerequisite for the job, and encourages responsibility especially for soft skills and students' access to these skills as well as solid skills through the undergraduate stage, which has a significant impact on students in developing their skills in this period, The study aims to raise awareness about the importance of soft skills and encourage students to improve their skills by including these skills in combination with solid skills in the curriculum. These skills play an important role in shaping the personality of the individual. It is no less important than academic knowledge.

After this presentation of previous studies shows the importance of attention to the soft skills of university students, as these skills are no less important than the scientific knowledge (hard skills), which often reduce the interest of universities in various disciplines, where most studies linked between students possess soft skills and increase The researchers have noticed that there are no studies conducted in Saudi Arabia (within the science of researchers) looking at the importance of soft skills, and this study may be the beginning to draw attention to the importance of this subject and attention to the wider, and Especially that the Kingdom is now moving strongly towards a new vision focused on human resources in light of the decline in the prices of natural resources, especially oil, and this promotes the graduation of a generation of students with solid skills and soft together.

\section{Method AND PROCEDURES}

\section{A. Methodology of the Study}

The researchers used the quantitative approach that is appropriate to the nature of the study and its questions. The data were entered into the SPSS program and the appropriate statistical methods were used for each of the study questions.

\section{B. Study Society}

The study population is composed of all the students of the Special Education Department at the College of Education, Princess Nourah Bint Abdul Rahman University for the academic year 1438-1439 AH (2017-2018). The total number of students is 3000 students divided into 3 specializations (learning difficulties, autism, And mental excellence). The study society is composed of all faculty members of the Special Education Department, Faculty of Education, Princess Nourah University. The faculty consists of (26) teaching staff, specializing in learning difficulties, autism, talent and mental excellence.

\section{The Study Sample}

The study tools were applied to a random sample of students of the Special Education Department at the Faculty of Education, Princess Nourah Bint Abdul Rahman University, from different disciplines and levels of study. The sample of the members of the teaching staff was applied to all faculty members in the special education department, Princess Nora, and table (1) build the sample members.

\section{Study Tools}

The study tool was developed by reference to the literature related to soft skills, as well as through the adoption of the views of a number of specialists working in the field of special education, and through these procedures prepared the first two tools (6) paragraphs, each of the following skills: creative thinking, critical thinking, communication and communication with others, dialogue, dealing and self-management, intelligence Emotional, Teamwork, decision making, problem solving, and time management skills. The validity of the scale was ascertained by finding signs of honesty and persistence in the following ways:

TABLE I. SHOWS THE SAMPLE OF THE STUDY ACCORDING TO THE VARIABLES OF SPECIALIZATION, EXPERIENCE, LEVEL OF STUDY

\begin{tabular}{|c|c|c|c|c|c|c|}
\hline \multirow[b]{2}{*}{ Total } & \multicolumn{5}{|c|}{ Total experience } & \multirow[b]{2}{*}{ Faculty members } \\
\hline & $\begin{array}{l}\text { older } \\
\text { than } \\
10 \\
\text { years }\end{array}$ & $\begin{array}{l}\text { from } \\
8 \\
\text { years } \\
\text { to } 10 \\
\text { years }\end{array}$ & $\begin{array}{l}\text { older } \\
\text { than } 4 \\
\text { years } \\
\text { and } \\
\text { less } \\
\text { than } 8\end{array}$ & \multicolumn{2}{|c|}{$\begin{array}{l}\text { less than } \\
4 \text { years }\end{array}$} & \\
\hline 14 & 2 & 2 & 2 & \multicolumn{2}{|l|}{8} & \multirow{4}{*}{$\begin{array}{l}\text { Autism } \\
\text { Learning difficultie } \\
\text { Talent } \\
\text { Total }\end{array}$} \\
\hline 7 & 0 & 0 & 4 & \multicolumn{2}{|l|}{3} & \\
\hline 5 & 0 & 0 & 5 & \multicolumn{2}{|l|}{0} & \\
\hline 26 & 2 & 2 & 12 & \multicolumn{2}{|c|}{11} & \\
\hline \multicolumn{2}{|l|}{ Total } & \multicolumn{4}{|c|}{ Total academic level } & \\
\hline & $\begin{array}{l}\text { Fourth } \\
\text { year }\end{array}$ & $\begin{array}{l}\text { Third } \\
\text { year }\end{array}$ & $\begin{array}{l}\text { Seco } \\
\text { year }\end{array}$ & & $\begin{array}{l}\text { First } \\
\text { year }\end{array}$ & Students \\
\hline 175 & 100 & 51 & 20 & & 4 & Autism \\
\hline 112 & 41 & 48 & 21 & & 2 & Learning difficulti \\
\hline 287 & 141 & 99 & 41 & & 6 & Total \\
\hline
\end{tabular}


TABLE II. COEFFICIENT OF CONSISTENCY IN THE INTERNAL CONSISTENCY METHOD OF THE EQUATION OF THE CRONBACH ALPHA EQUATION TO THE EXTENT OF POSSESSING THE SOFT SKILLS OF THE SAMPLE OF FEMALE STUDENTS AND FACULTY MEMBERS

\begin{tabular}{|c|c|c|c|}
\hline $\begin{array}{r}\text { Kronbach } \\
\text { Alpha }\end{array}$ & $\begin{array}{r}\text { Kronbach } \\
\text { Alpha }\end{array}$ & & \\
\hline $\begin{array}{r}\text { Paragraphs } \\
\text { for faculty } \\
\text { members }\end{array}$ & $\begin{array}{r}\text { Paragraphs } \\
\text { for female } \\
\text { students }\end{array}$ & Paragraphs & Dimensions \\
\hline ,723 & ,761 & 7 & Creative thinking \\
\hline ,732 & 801 & 7 & Critical thinking \\
\hline ,763 & ,733 & 7 & $\begin{array}{r}\text { Communicate and } \\
\text { communicate with others }\end{array}$ \\
\hline, 772 & ,732 & 7 & Dialogue \\
\hline 802 & ,760 & 7 & Dealing and self-management \\
\hline, 783 &, 731 & 7 & emotional smartness \\
\hline ,742 & ,771 & 7 & $\begin{array}{l}\text { Teamwork } \\
\text { (Team work) }\end{array}$ \\
\hline ,751 & ,750 & 7 & $\begin{array}{r}\text { Decision making and problem } \\
\text { solving }\end{array}$ \\
\hline, 740 & ,741 & 7 & time management skill \\
\hline .756 & .753 & & Total \\
\hline
\end{tabular}

1) Honesty: (7) arbitrators with specializations in the field of special education, psychology, measurement and evaluation, and asked each arbitrator to express his opinion in the paragraphs of the scale in terms of the degree of belonging to paragraph The second dimension concerns the linguistic language proposed by the arbitrators. The second dimension is the linguistic amendments proposed by the arbitrators. The second dimension concerns the linguistic changes proposed by the arbitrators. Adoption of a standard agreement $(80 \%)$ of the arbitrators to accept paragraph and accordingly have been some linguistic amendments to some of the paragraphs in the standard procedure.

2) Stability: The stability of the scale was verified in an internal consistency method by the formula of the Cronbach alpha equation, after applying it to 30 students and 9 faculty members. Table (2) establishes the stability coefficient.

The table indicates that the total value of the Cronbach Alpha for the female students was (753), which is acceptable values for the purposes of the study, and the value of Cronbach Alpha for the scale of faculty members amounted to (756), which are acceptable values for the purposes of study.

\section{E. Correction of Study Tools}

The answer scale for soft skill measures was five alternatives; the answer ladder was (strongly agree, agree, neutral, disagree, not strongly agree). The researchers gave the paragraphs five scores for the answer, which represented the strongly approved alternative, , Three responses to the softskill scale (63-315), and the researchers used the statistical criterion for judging the average number of vertebrates And dimensions; so if The average values of the arithmetical averages ranged from (1 - less than 2.33), medium between (3.66 - 2.33) and high if they ranged between (3.67 - 5.00).

\section{F. Statistical Analysis}

In order to answer the survey questions, the data in the scale were abstracted and statistically analyzed using the SPSS. Statistical methods were used to answer each of the study questions. The mean averages, the standard deviations, and the $\mathrm{T}$ test were used to answer the question. Third, the ANOVA test and the LSD test to answer the third and fourth question.

\section{RESULTS}

This study aimed at the degree of ownership of special education students at Princess Nourah University for soft skills from their point of view and the consideration of the educational body. This study came out with a set of results, as follows:

To answer the first question of this study, which states: "What is the degree to which students of the Department of Special Education for soft skills from their point of view?" Mean averages and deviations were calculated for the degree of female students' possession of soft skills and standard deviations. Table (3) shows the results of the analysis.

It is noted in Table (3) that the highest average of the students' proficiency score for soft skills from their point of view was for the following paragraphs in the third dimension: After contacting and communicating with others, the high arithmetic mean was the second: "I have the ability to use the library (4.35). On the fourth dimension of the skill of dialogue, the first, second and third paragraphs, which read respectively: "Be careful to call the most recent of his name, or his nickname that he loves" and "I commend the other side "I think the counter-attack often leads to a futile confrontation with the other side" with a high arithmetic mean. The average of these paragraphs respectively was as follows: the first paragraph was average (4.39) and the second paragraph averaged 4.37), while the arithmetic average of the third paragraph $(4,10)$, and in respect of the seventh dimension, after the skill of teamwork (work within the team), the third paragraph, which was "Share the members of the group in setting goals and making decisions" This dimension has an average of (4.26) and in terms of the eighth dimension related to the skill of decision-making and solving Problems, the second, fifth and sixth paragraphs had a high arithmetic mean, and the text of these paragraphs, respectively, was: "I advise everyone who will be affected by the decision before it is taken", "determine the benefits and disadvantages of the decision before it is taken" and "proceed with the satisfactory decision" The mean arithmetic mean for these paragraphs respectively is (4.12), (4.03) and (4.04). The third paragraph, which read "spend time for leisure", was the highest with an average of $4.11,9$, on the skill of time management, the third paragraph, which read "make sure to spend time to entertain" is the paragraph with the highest arithmetic mean in this The average score of students was 4.11 , with a mean average of 4,11 . Table 3 indicates that the students' degree of soft skills from their point of view was low on the first, third, sixth and seventh dimensions and the total score, which is intermediate on the second, fourth, eighth and ninth dimensions. 
TABLE III. MATHEMATICAL AVERAGES AND STANDARD DEVIATIONS OF STUDENTS' DEGREE OF SOFT SKILLS FROM THEIR POINT OF VIEW

\begin{tabular}{|c|c|c|c|c|c|c|}
\hline Class & $\begin{array}{l}\text { Standard } \\
\text { Deviation }\end{array}$ & Average & Extreme & Micro & $\mathrm{N}$ & Paragraph \\
\hline Average & .91121 & 3.7046 & 5.00 & 1.00 & 281 & 1 \\
\hline Average & .97451 & 3.8198 & 5.00 & 1.00 & 283 & 2 \\
\hline Average & .76589 & 4.1853 & 5.00 & 1.00 & 286 & 3 \\
\hline Average & .78992 & 4.1469 & 5.00 & 1.00 & 286 & 4 \\
\hline Average & .76576 & 4.2203 & 5.00 & 1.00 & 286 & 5 \\
\hline Low & 3.15966 & 19.9024 & 27.00 & 1.00 & 287 & $\mathrm{~d} 1$ \\
\hline Average & 1.16480 & 3.2125 & 5.00 & 1.00 & 287 & 1 \\
\hline Average & .79655 & 4.0245 & 5.00 & 2.00 & 286 & 2 \\
\hline Average & .86293 & 4.0105 & 5.00 & 1.00 & 287 & 3 \\
\hline Average & .74783 & 3.9861 & 5.00 & 2.00 & 287 & 4 \\
\hline Average & .79933 & 3.8780 & 5.00 & 2.00 & 287 & 5 \\
\hline Average & .75955 & 4.1119 & 5.00 & 1.00 & 286 & 6 \\
\hline Average & .71945 & 4.2125 & 5.00 & 1.00 & 287 & 7 \\
\hline Average & 3.46476 & 27.4077 & 35.00 & 14.00 & 287 & $\mathrm{~d} 2$ \\
\hline Average & .92342 & 4.0209 & 5.00 & 1.00 & 287 & 1 \\
\hline Average & 1.00992 & 4.1359 & 5.00 & 1.00 & 287 & 2 \\
\hline Average & 1.04420 & 3.8118 & 5.00 & 1.00 & 287 & 3 \\
\hline Average & .81616 & 4.3937 & 5.00 & 1.00 & 287 & 4 \\
\hline Average & .87232 & 4.2448 & 5.00 & 2.00 & 286 & 5 \\
\hline Average & .88905 & 3.2648 & 4.00 & 1.00 & 287 & 6 \\
\hline High & .84876 & 4.3589 & 5.00 & 1.00 & 287 & 7 \\
\hline Low & 4.80334 & 29.2160 & 68.00 & 14.00 & 287 & $\mathrm{~d} 3$ \\
\hline High & .85966 & 4.3763 & 5.00 & 1.00 & 287 & 1 \\
\hline High & .76905 & 4.3986 & 5.00 & 2.00 & 286 & 2 \\
\hline High & .89528 & 4.1056 & 5.00 & 1.00 & 284 & 3 \\
\hline Average & .98427 & 3.8049 & 5.00 & .00 & 287 & 4 \\
\hline Average & 1.21453 & 3.2648 & 5.00 & -4.00 & 287 & 5 \\
\hline Average & .89871 & 3.9965 & 5.00 & 1.00 & 287 & 6 \\
\hline Average & .85689 & 4.0000 & 5.00 & 1.00 & 287 & 7 \\
\hline Average & 3.98706 & 27.8885 & 35.00 & 11.00 & 287 & $\mathrm{~d} 4$ \\
\hline Average & 1.03746 & 3.7038 & 5.00 & 1.00 & 287 & 1 \\
\hline Average & 1.08906 & 3.8153 & 5.00 & 1.00 & 287 & 2 \\
\hline Average & .76563 & 4.0348 & 5.00 & 2.00 & 287 & 3 \\
\hline Average & .94927 & 3.9126 & 5.00 & 1.00 & 286 & 4 \\
\hline Average & .85110 & 3.7805 & 5.00 & 1.00 & 287 & 5 \\
\hline Average & 1.03382 & 3.8287 & 5.00 & 1.00 & 286 & 6 \\
\hline
\end{tabular}

\begin{tabular}{|c|c|c|c|c|c|c|}
\hline Class & $\begin{array}{l}\text { Standard } \\
\text { Deviation }\end{array}$ & Average & Extreme & Micro & $\mathrm{N}$ & Paragraph \\
\hline Average & 1.08286 & 3.7666 & 5.00 & 1.00 & 287 & 7 \\
\hline Low & 4.78240 & 26.8153 & 47.00 & 11.00 & 287 & d5 \\
\hline Average & 1.06239 & 3.5575 & 5.00 & 1.00 & 287 & 1 \\
\hline Average & .90284 & 3.9231 & 5.00 & 1.00 & 286 & 2 \\
\hline Average & .89952 & 4.0699 & 5.00 & 1.00 & 286 & 3 \\
\hline Average & .87907 & 4.2028 & 5.00 & 1.00 & 286 & 4 \\
\hline Average & .98163 & 3.8632 & 5.00 & .00 & 285 & 5 \\
\hline Average & 1.24380 & 3.4545 & 5.00 & 1.00 & 286 & 6 \\
\hline Average & 1.10251 & 3.8077 & 11.00 & 1.00 & 286 & 7 \\
\hline Low & 4.50664 & 26.7840 & 39.00 & 4.00 & 287 & d6 \\
\hline Average & .75068 & 4.1608 & 5.00 & 1.00 & 286 & 1 \\
\hline Average & .90855 & 4.0979 & 5.00 & 1.00 & 286 & 2 \\
\hline High & .78881 & 4.2622 & 5.00 & 1.00 & 286 & 3 \\
\hline High & .81150 & 4.1364 & 5.00 & 1.00 & 286 & 4 \\
\hline Average & .86516 & 4.1719 & 5.00 & 1.00 & 285 & 5 \\
\hline Average & .89600 & 3.8239 & 5.00 & 1.00 & 284 & 6 \\
\hline Average & .77699 & 4.1014 & 5.00 & 1.00 & 286 & 7 \\
\hline Low & 4.49167 & 28.6132 & 41.00 & 19.00 & 287 & d7 \\
\hline Average & .92382 & 4.1538 & 5.00 & 1.00 & 286 & 1 \\
\hline High & .77112 & 4.1259 & 5.00 & 1.00 & 286 & 2 \\
\hline Average & .81170 & 3.9720 & 5.00 & .00 & 286 & 3 \\
\hline Average & .82347 & 3.9021 & 5.00 & 2.00 & 286 & 4 \\
\hline High & .79835 & 4.0350 & 5.00 & 2.00 & 286 & 5 \\
\hline High & .73735 & 4.0456 & 5.00 & 1.00 & 285 & 6 \\
\hline Average & .72500 & 4.2657 & 5.00 & 1.00 & 286 & 7 \\
\hline Average & 4.30078 & 28.3868 & 37.00 & 19.00 & 287 & d8 \\
\hline Average & .88158 & 3.9580 & 5.00 & 1.00 & 286 & 1 \\
\hline Average & 1.06088 & 3.6748 & 5.00 & 1.00 & 286 & 2 \\
\hline High & .84998 & 4.1158 & 5.00 & 1.00 & 285 & 3 \\
\hline Average & .76486 & 4.2993 & 5.00 & 1.00 & 284 & 4 \\
\hline Average & .98346 & 3.4196 & 5.00 & 1.00 & 286 & 5 \\
\hline Average & .88239 & 4.1783 & 5.00 & 1.00 & 286 & 6 \\
\hline Average & 1.04103 & 3.7552 & 5.00 & 1.00 & 286 & 7 \\
\hline Average & 4.11096 & 27.2613 & 35.00 & 19.00 & 287 & d9 \\
\hline Low & 24.91379 & 242.2753 & 329.00 & 127.00 & 287 & Total \\
\hline
\end{tabular}

To answer the second question of this study, which states: "What is the degree to which the students of the special education department have soft skills from the point of view of the members of the faculty?" The average and standard deviations of students' degree of soft skills and standard deviations were calculated. Table (4) shows the results of the analysis. 
It is noted in Table (4) that the highest assessment of skills according to the point of view of the faculty was the second dimension, which relates to the skill of critical thinking, and the high estimate of the fourth paragraph only, which was written "students have the ability to compare different views" Paragraph 3.38, as well as the assessment of the fifth dimension related to the skill of communication and communication with others. The high assessment of paragraph 5 , which read "listen carefully to the speaker", reached the mathematical average of this paragraph (3.73) VII Skill Teamwork (Action Combine "The students are seeking to find effective means of work and appropriate tools to achieve the objectives of the working group." The average of this paragraph is 3,46 . Table 4 indicates that the degree of the total evaluation of faculty members for female students Overall soft skills were low, also low on the first, second, fifth, sixth, eighth and ninth dimensions, which are medium on the third, fourth and seventh dimensions. There is no high rating except for some of the paragraphs to which we referred.

TABLE IV. The AVERAge ASSESSMENT OF FACUlty MEMBERS OF FEMALE STUDENTS ON THE PARAGRAPHS AND DIMENSIONS AND THE TOTAL SCORE

\begin{tabular}{|l|l|l|l|l|l|}
\hline Class & $\begin{array}{l}\text { Standard } \\
\text { Deviation }\end{array}$ & Average & High & Micro & \\
\hline Average & 1.0318 & 3.2308 & 5 & 2 & 1 \\
\hline Average & 0.97744 & 2.6538 & 5 & 1 & 2 \\
\hline Average & 1.05903 & 3.1923 & 5 & 1 & 3 \\
\hline Low & 0.8709 & 2.9615 & 5 & 1 & 4 \\
\hline Average & 0.97033 & 3.3077 & 5 & 2 & 5 \\
\hline Average & 0.85934 & 3.5385 & 5 & 2 & 6 \\
\hline Low & 0.97665 & 2.9231 & 5 & 2 & 7 \\
\hline Low & 4.648 & 21.81 & 35 & 15 & $\mathrm{~d} 1$ \\
\hline Average & 0.98684 & 3.4231 & 5 & 1 & 1 \\
\hline Average & 0.84853 & 3 & 4 & 2 & 2 \\
\hline Average & 0.8709 & 3.0385 & 4 & 2 & 3 \\
\hline High & 0.75243 & 3.3846 & 4 & 2 & 4 \\
\hline Average & 0.78446 & 2.8462 & 4 & 2 & 5 \\
\hline Average & 0.52769 & 3.9615 & 5 & 3 & 6 \\
\hline Low & 1.10732 & 2.8846 & 5 & 1 & 7 \\
\hline Low & 2.901 & 22.54 & 28 & 19 & $\mathrm{~d} 2$ \\
\hline Average & 1.0198 & 3 & 5 & 2 & 1 \\
\hline Average & 1.03255 & 2.8846 & 5 & 1 & 2 \\
\hline Average & 1.03255 & 3.1154 & 5 & 1 & 3 \\
\hline Average & 0.80861 & 3.5769 & 5 & 2 & 4 \\
\hline High & 0.45234 & 3.7308 & 4 & 3 & 5 \\
\hline Average & 0.98917 & 3.4615 & 5 & 1 & 6 \\
\hline Average & 1.2083 & 3.5 & 5 & 1 & 7 \\
\hline Average & 4.172 & 23.27 & 30 & 15 & $\mathrm{~d} 3$ \\
\hline Average & 0.71036 & 3.7692 & 5 & 2 & 1 \\
\hline Average & 0.84943 & 3.8077 & 5 & 1 & 2 \\
\hline Average & 0.70711 & 3.5 & 4 & 2 & 3 \\
\hline Average & 0.91903 & 3.2692 & 5 & 2 & \\
\hline & & & & & 1 \\
\hline
\end{tabular}

\begin{tabular}{|c|c|c|c|c|c|}
\hline Class & $\begin{array}{l}\text { Standard } \\
\text { Deviation }\end{array}$ & Average & High & Micro & \\
\hline Average & 0.8339 & 2.8462 & 4 & 1 & 5 \\
\hline High & 0.53349 & 3.7308 & 4 & 2 & 6 \\
\hline Average & 0.96157 & 2.7308 & 4 & 1 & 7 \\
\hline Average & 2.697 & 23.65 & 28 & 20 & $\mathrm{~d} 4$ \\
\hline Average & 0.8339 & 3.1538 & 5 & 1 & 1 \\
\hline Average & 0.88405 & 3.3077 & 5 & 1 & 2 \\
\hline Average & 0.81146 & 3.4615 & 5 & 2 & 3 \\
\hline Low & 0.86291 & 3.2308 & 5 & 2 & 4 \\
\hline Low & 0.8709 & 2.9615 & 5 & 2 & 5 \\
\hline Average & 0.9389 & 3.1923 & 5 & 2 & 6 \\
\hline Low & 0.89529 & 3.1923 & 5 & 1 & 7 \\
\hline Low & 4.283 & 22.5 & 35 & 15 & $\mathrm{~d} 5$ \\
\hline Average & 0.97665 & 3.0769 & 5 & 1 & 1 \\
\hline Average & 0.91568 & 3.0385 & 4 & 1 & 2 \\
\hline Low & 0.95836 & 2.9615 & 5 & 2 & 3 \\
\hline Low & 0.83758 & 3.3077 & 5 & 2 & 4 \\
\hline Low & 0.78838 & 3.3077 & 4 & 1 & 5 \\
\hline Low & 0.67937 & 3.6923 & 5 & 2 & 6 \\
\hline Average & 0.71036 & 3.7692 & 5 & 3 & 7 \\
\hline Low & 3.184 & 23.15 & 31 & 18 & d6 \\
\hline Average & 1.15825 & 3.3077 & 5 & 1 & 1 \\
\hline Average & 0.98917 & 3.4615 & 5 & 1 & 2 \\
\hline Average & 0.78838 & 3.6923 & 5 & 1 & 3 \\
\hline Average & 1.04954 & 3.3077 & 5 & 1 & 4 \\
\hline Average & 0.90469 & 3.4615 & 5 & 1 & 5 \\
\hline Average & 0.84853 & 3 & 4 & 1 & 6 \\
\hline High & 0.80861 & 3.4231 & 4 & 1 & 7 \\
\hline Average & 5.161 & 23.65 & 31 & 7 & d7 \\
\hline Low & 0.86291 & 3.2308 & 5 & 2 & 1 \\
\hline Average & 0.89184 & 3.3462 & 5 & 1 & 2 \\
\hline Average & 0.86291 & 3.2308 & 5 & 2 & 3 \\
\hline Low & 0.74936 & 3.1923 & 5 & 2 & 4 \\
\hline Low & 0.86291 & 3.2308 & 5 & 2 & 5 \\
\hline Low & 0.80096 & 3.1923 & 5 & 2 & 6 \\
\hline Average & 0.94787 & 3.4615 & 5 & 1 & 7 \\
\hline Low & 4.246 & 22.88 & 33 & 13 & $\mathrm{~d} 8$ \\
\hline Average & 1.00231 & 3.2692 & 5 & 1 & 1 \\
\hline Average & 1.03849 & 3.0385 & 5 & 1 & 2 \\
\hline Average & 0.89786 & 3.6154 & 5 & 1 & 3 \\
\hline Average & 0.68836 & 4.0769 & 5 & 2 & 4 \\
\hline Average & 0.82741 & 3.7308 & 5 & 2 & 5 \\
\hline Average & 0.96157 & 2.7308 & 5 & 1 & 6 \\
\hline Average & 0.99305 & 3.1154 & 5 & 2 & 7 \\
\hline Low & 4.081 & 23.58 & 32 & 17 & d9 \\
\hline Low & 26.386 & 207.04 & 274 & 157 & \\
\hline
\end{tabular}

In order to answer the third question: "Is there a significant difference at the level of (0.05) to the extent that the students of the Department of Special Education for soft skills from their point of view are attributed to the variable of specialization and level of school? The specialization and Table (5) shows the results of the analysis.

Table (5) indicates that there is a virtual difference on the dimensions of the total score due to the specialization variable and to see if the difference D was statistically tested (T) for the difference between the averages as in the following table. 
TABLE V. Shows the CALCUlation OF PeRFormanCE AVERAGES by SPECIALIZATION VARIABLE

\begin{tabular}{|c|c|c|c|c|c|}
\hline $\begin{array}{l}\text { Mean } \\
\text { Standard } \\
\text { Error }\end{array}$ & $\begin{array}{l}\text { Standard } \\
\text { Deviation }\end{array}$ & Average & $\mathbf{N}$ & Specialty & \\
\hline .22510 & 2.97783 & 19.8914 & 175 & Autism & \multirow{2}{*}{$\mathrm{d} 1$} \\
\hline .32489 & 3.43836 & 19.9196 & 112 & Learning difficulties & \\
\hline .26494 & 3.50479 & 27.5486 & 175 & Autism & \multirow{2}{*}{$\mathrm{d} 2$} \\
\hline .32176 & 3.40517 & 27.1875 & 112 & Learning difficulties & \\
\hline .38231 & 5.05745 & 29.0514 & 175 & Autism & \multirow{2}{*}{$\mathrm{d} 3$} \\
\hline .41450 & 4.38663 & 29.4732 & 112 & Learning difficulties & \\
\hline .30547 & 4.04105 & 28.0571 & 175 & Autism & \multirow{2}{*}{$\mathrm{d} 4$} \\
\hline .36895 & 3.90455 & 27.6250 & 112 & Learning difficulties & \\
\hline .36186 & 4.78694 & 26.7886 & 175 & Autism & \multirow{2}{*}{ d5 } \\
\hline .45323 & 4.79650 & 26.8571 & 112 & Learning difficulties & \\
\hline .32658 & 4.32030 & 26.9143 & 175 & Autism & \multirow{2}{*}{ d6 } \\
\hline .45319 & 4.79609 & 26.5804 & 112 & Learning difficulties & \\
\hline .32594 & 4.31184 & 28.5657 & 175 & Autism & \multirow{2}{*}{ d7 } \\
\hline .45148 & 4.77801 & 28.6875 & 112 & Learning difficulties & \\
\hline .29669 & 3.92489 & 28.2457 & 175 & Autism & \multirow{2}{*}{$\mathrm{d} 8$} \\
\hline .45738 & 4.84044 & 28.6071 & 112 & Learning difficulties & \\
\hline .28433 & 3.76135 & 27.2857 & 175 & Autism & \multirow{2}{*}{ d9 } \\
\hline .43675 & 4.62214 & 27.2232 & 112 & Learning difficulties & \\
\hline 1.87175 & 24.76090 & 242.3486 & 175 & Autism & \multirow{2}{*}{$\begin{array}{l}\text { Tot } \\
\text { al }\end{array}$} \\
\hline 2.38704 & 25.26207 & 242.1607 & 112 & Learning difficulties & \\
\hline
\end{tabular}

TABLE VI. THE RESUlts OF THE TEST (T) FOR THE DIFFERENCE BETWEEN THE AVERAGES ACCORDING TO THE SPECIALIZATION VARIABLE

\begin{tabular}{|l|l|l|l|l|l|}
\hline $\begin{array}{l}\text { Variance of } \\
\text { Standard } \\
\text { Deviation }\end{array}$ & $\begin{array}{l}\text { Average } \\
\text { Variation }\end{array}$ & Significance & $\begin{array}{l}\text { Degree } \\
\text { of } \\
\text { freedom }\end{array}$ & $\mathbf{T}$ & \\
\hline .38301 & -.02821 & .941 & 285 & -.074 & $\mathrm{~d} 1$ \\
\hline .41945 & .36107 & .390 & 285 & .861 & $\mathrm{~d} 2$ \\
\hline .58172 & -.42179 & .469 & 285 & -.725 & $\mathrm{~d} 3$ \\
\hline .48263 & .43214 & .371 & 285 & .895 & $\mathrm{~d} 4$ \\
\hline .57971 & -.06857 & .906 & 285 & -.118 & $\mathrm{~d} 5$ \\
\hline .54594 & .33393 & .541 & 285 & .612 & $\mathrm{~d} 6$ \\
\hline .54443 & -.12179 & .823 & 285 & -.224 & $\mathrm{~d} 7$ \\
\hline .52090 & -.36143 & .488 & 285 & -.694 & $\mathrm{~d} 8$ \\
\hline .49832 & .06250 & .900 & 285 & .125 & $\mathrm{~d} 9$ \\
\hline 3.02002 & .18786 & .950 & 285 & .062 & total \\
\hline
\end{tabular}

Table (6) indicates that there is no statistically significant difference between the averages due to the specialization variable.

In order to answer the question about the effect of the variable of the academic level, to the extent that students have soft skills according to their point of view, which were: Are there statistically significant differences at the level of $(0,05)$ Study Analysis of the common variation of the differences between the averages by the variable of the study level was conducted as shown in Table (7).
TABLE VII. THE RESUlTS OF THE ANOVA TEST ARE BASED ON THE DIFFERENCE BETWEEN THE AVERAGES BY THE VARIABLE OF THE STUDY LEVEL

\begin{tabular}{|c|c|c|c|c|c|c|}
\hline $\begin{array}{l}\text { Level of } \\
\text { Significance }\end{array}$ & $\begin{array}{l}\text { F } \\
\text { VALUE }\end{array}$ & $\begin{array}{l}\text { Average } \\
\text { Squares }\end{array}$ & $\begin{array}{l}\text { Degree } \\
\text { of } \\
\text { freedom }\end{array}$ & $\begin{array}{l}\text { Total } \\
\text { Squares }\end{array}$ & & \\
\hline \multirow[t]{3}{*}{.387} & 1.013 & 10.108 & 3 & 30.324 & $\begin{array}{l}\begin{array}{l}\text { Between } \\
\text { groups }\end{array} \\
\end{array}$ & \multirow{3}{*}{$\mathrm{d} 1$} \\
\hline & & 9.982 & 283 & 2824.945 & $\begin{array}{l}\text { In the } \\
\text { groups }\end{array}$ & \\
\hline & & & 286 & 2855.268 & Total & \\
\hline \multirow[t]{3}{*}{.450} & .884 & 10.622 & 3 & 31.866 & $\begin{array}{l}\text { Between } \\
\text { groups }\end{array}$ & \multirow{3}{*}{$\mathrm{d} 2$} \\
\hline & & 12.019 & 283 & 3401.437 & $\begin{array}{l}\text { In the } \\
\text { groups }\end{array}$ & \\
\hline & & & 286 & 3433.303 & Total & \\
\hline \multirow[t]{3}{*}{.462} & .861 & 19.891 & 3 & 59.673 & $\begin{array}{l}\text { Between } \\
\text { groups }\end{array}$ & \multirow{3}{*}{$\mathrm{d} 3$} \\
\hline & & 23.106 & 283 & 6538.933 & $\begin{array}{l}\text { In the } \\
\text { groups }\end{array}$ & \\
\hline & & & 286 & 6598.606 & Total & \\
\hline \multirow[t]{3}{*}{.007} & 4.126 & 63.510 & 3 & 190.529 & $\begin{array}{l}\text { Between } \\
\text { groups }\end{array}$ & \multirow{3}{*}{$\mathrm{d} 4$} \\
\hline & & 15.392 & 283 & 4355.903 & $\begin{array}{l}\text { In the } \\
\text { groups }\end{array}$ & \\
\hline & & & 286 & 4546.432 & Total & \\
\hline \multirow[t]{3}{*}{.069} & 2.387 & 53.814 & 3 & 161.443 & $\begin{array}{l}\text { Between } \\
\text { groups }\end{array}$ & \multirow{3}{*}{ d5 } \\
\hline & & 22.543 & 283 & 6379.770 & $\begin{array}{l}\text { In the } \\
\text { groups }\end{array}$ & \\
\hline & & & 286 & 6541.213 & Total & \\
\hline \multirow[t]{3}{*}{.295} & 1.242 & 25.158 & 3 & 75.473 & $\begin{array}{l}\text { Between } \\
\text { groups }\end{array}$ & \multirow{3}{*}{ d6 } \\
\hline & & 20.258 & 283 & 5733.134 & $\begin{array}{l}\text { In the } \\
\text { groups }\end{array}$ & \\
\hline & & & 286 & 5808.606 & Total & \\
\hline \multirow[t]{3}{*}{.094} & 2.154 & 42.939 & 3 & 128.816 & $\begin{array}{l}\text { Between } \\
\text { groups }\end{array}$ & \multirow{3}{*}{ d7 } \\
\hline & & 19.934 & 283 & 5641.254 & $\begin{array}{l}\text { In the } \\
\text { groups }\end{array}$ & \\
\hline & & & 286 & 5770.070 & Total & \\
\hline \multirow[t]{3}{*}{.434} & .915 & 16.947 & 3 & 50.842 & $\begin{array}{l}\text { Between } \\
\text { groups }\end{array}$ & \multirow{3}{*}{$\mathrm{d} 8$} \\
\hline & & 18.513 & 283 & 5239.227 & $\begin{array}{l}\begin{array}{l}\text { In the } \\
\text { groups }\end{array} \\
\end{array}$ & \\
\hline & & & 286 & 5290.070 & Total & \\
\hline \multirow[t]{3}{*}{.010} & 3.821 & 62.721 & 3 & 188.163 & $\begin{array}{l}\begin{array}{l}\text { Between } \\
\text { groups }\end{array} \\
\end{array}$ & \multirow{3}{*}{ d9 } \\
\hline & & 16.414 & 283 & 4645.238 & $\begin{array}{l}\text { In the } \\
\text { groups }\end{array}$ & \\
\hline & & & 286 & 4833.401 & Total & \\
\hline \multirow[t]{3}{*}{.041} & 2.782 & $\begin{array}{l}1695.05 \\
2\end{array}$ & 3 & 5085.155 & $\begin{array}{l}\text { Between } \\
\text { groups }\end{array}$ & \multirow{3}{*}{$\begin{array}{l}\text { tota } \\
1\end{array}$} \\
\hline & & 609.308 & 283 & $\begin{array}{l}172434.0 \\
99\end{array}$ & $\begin{array}{l}\text { In the } \\
\text { groups }\end{array}$ & \\
\hline & & & 286 & $\begin{array}{l}177519.2 \\
54\end{array}$ & Total & \\
\hline
\end{tabular}


Table (7) shows that there is a statistically significant difference in the fourth, ninth, and total dimensions. There is no statistically significant difference between the first, second, third, fifth, sixth, seventh and eighth dimensions.

LSD test (least significant differences) was performed for the post-comparisons as shown in Table (8).

Table (8) shows that the difference in the fourth, ninth, and total score tends to favor the larger school years.

The fourth answer: Are there significant differences at the level of $(0,05)$ to the degree of possession of female students of the Department of Special Education for soft skills from the point of view of the members of the Education Council due to the variables of experience and specialization?

ANOVA was analyzed to answer the question. Table (9) analyzes the results of this question.

TABLE VIII. Shows the Distance Comparisons (LSD) OF THE DIFFERENCE BETWEEN THE AVERAGES

\begin{tabular}{|c|c|c|c|c|c|}
\hline $\begin{array}{l}\text { Level of } \\
\text { Significance. }\end{array}$ & $\begin{array}{l}\text { Standard } \\
\text { Error }\end{array}$ & $\begin{array}{l}\text { Average } \\
\text { Contrast } \\
\text { (I-J) }\end{array}$ & $\begin{array}{l}\text { Level } \\
\text { of } \\
\text { Study }\end{array}$ & $\begin{array}{l}\text { Level } \\
\text { of } \\
\text { Study }\end{array}$ & Dimension \\
\hline .331 & 1.71485 & -1.67073 & $\begin{array}{l}\text { Second } \\
\text { year }\end{array}$ & \multirow{3}{*}{$\begin{array}{l}\text { First } \\
\text { year }\end{array}$} & \multirow{12}{*}{$\mathrm{d} 4$} \\
\hline .303 & 1.64948 & -1.70202 & $\begin{array}{l}\text { Third } \\
\text { year }\end{array}$ & & \\
\hline .053 & 1.63538 & -3.18085 & $\begin{array}{l}\text { Fourth } \\
\text { year }\end{array}$ & & \\
\hline .331 & 1.71485 & 1.67073 & $\begin{array}{l}\text { First } \\
\text { year }\end{array}$ & & \\
\hline .966 & .72862 & -.03129 & $\begin{array}{l}\text { Second } \\
\text { year }\end{array}$ & $\begin{array}{l}\text { Second } \\
\text { year }\end{array}$ & \\
\hline .031 & .69611 & $-1.51012^{*}$ & $\begin{array}{l}\text { Fourth } \\
\text { year }\end{array}$ & & \\
\hline .303 & 1.64948 & 1.70202 & $\begin{array}{l}\text { First } \\
\text { year }\end{array}$ & \multirow{3}{*}{$\begin{array}{l}\text { Third } \\
\text { year }\end{array}$} & \\
\hline .966 & .72862 & .03129 & $\begin{array}{l}\text { Second } \\
\text { year }\end{array}$ & & \\
\hline .004 & .51443 & $-1.47883 *$ & $\begin{array}{l}\text { Fourth } \\
\text { year }\end{array}$ & & \\
\hline .053 & 1.63538 & 3.18085 & $\begin{array}{l}\text { First } \\
\text { year }\end{array}$ & \multirow{3}{*}{$\begin{array}{l}\text { Fourth } \\
\text { year }\end{array}$} & \\
\hline .031 & .69611 & $1.51012 *$ & $\begin{array}{l}\text { Second } \\
\text { year }\end{array}$ & & \\
\hline .004 & .51443 & $1.47883 *$ & $\begin{array}{l}\text { Second } \\
\text { year }\end{array}$ & & \\
\hline .077 & 1.77089 & -3.14634 & $\begin{array}{l}\text { Second } \\
\text { year }\end{array}$ & $\begin{array}{l}\text { First } \\
\text { year }\end{array}$ & d9 \\
\hline
\end{tabular}

\begin{tabular}{|c|c|c|c|c|c|}
\hline .011 & 1.70338 & $-4.35354^{*}$ & $\begin{array}{l}\text { Second } \\
\text { year }\end{array}$ & & \\
\hline .006 & 1.68882 & $-4.70213 *$ & $\begin{array}{l}\text { Fourth } \\
\text { year }\end{array}$ & & \\
\hline .077 & 1.77089 & 3.14634 & $\begin{array}{l}\text { First } \\
\text { year }\end{array}$ & \multirow{3}{*}{$\begin{array}{l}\text { Second } \\
\text { year }\end{array}$} & \\
\hline .110 & .75243 & -1.20719 & $\begin{array}{l}\text { Third } \\
\text { year }\end{array}$ & & \\
\hline .031 & .71886 & $-1.55579 *$ & $\begin{array}{l}\text { Fourth } \\
\text { year }\end{array}$ & & \\
\hline .011 & 1.70338 & $4.35354^{*}$ & $\begin{array}{l}\text { Second } \\
\text { year }\end{array}$ & \multirow{3}{*}{$\begin{array}{l}\text { Third } \\
\text { year }\end{array}$} & \\
\hline .110 & .75243 & 1.20719 & $\begin{array}{l}\text { Second } \\
\text { year }\end{array}$ & & \\
\hline .512 & .53124 & -.34859 & $\begin{array}{l}\text { First } \\
\text { year }\end{array}$ & & \\
\hline .006 & 1.68882 & $4.70213^{*}$ & $\begin{array}{l}\text { First } \\
\text { year }\end{array}$ & \multirow{3}{*}{$\begin{array}{l}\text { Fourth } \\
\text { year }\end{array}$} & \\
\hline .031 & .71886 & $1.55579 *$ & $\begin{array}{l}\text { Second } \\
\text { year }\end{array}$ & & \\
\hline .512 & .53124 & .34859 & $\begin{array}{l}\text { Third } \\
\text { year }\end{array}$ & & \\
\hline .192 & 10.78946 & -14.10976 & $\begin{array}{l}\text { Second } \\
\text { year }\end{array}$ & \multirow{3}{*}{$\begin{array}{l}\text { First } \\
\text { year }\end{array}$} & \multirow{12}{*}{ Total } \\
\hline .069 & 10.37815 & -18.91414 & $\begin{array}{l}\text { Second } \\
\text { year }\end{array}$ & & \\
\hline .027 & 10.28944 & $-22.86879^{*}$ & $\begin{array}{l}\text { Fourth } \\
\text { year }\end{array}$ & & \\
\hline .192 & 10.78946 & 14.10976 & $\begin{array}{l}\text { First } \\
\text { year }\end{array}$ & \multirow{3}{*}{$\begin{array}{l}\text { Second } \\
\text { year }\end{array}$} & \\
\hline .296 & 4.58430 & -4.80439 & $\begin{array}{l}\text { Third } \\
\text { year }\end{array}$ & & \\
\hline .046 & 4.37978 & $-8.75904 *$ & $\begin{array}{l}\text { Fourth } \\
\text { year }\end{array}$ & & \\
\hline .069 & 10.37815 & 18.91414 & $\begin{array}{l}\text { First } \\
\text { year }\end{array}$ & \multirow{3}{*}{$\begin{array}{l}\text { Third } \\
\text { year }\end{array}$} & \\
\hline .296 & 4.58430 & 4.80439 & $\begin{array}{l}\text { Second } \\
\text { year }\end{array}$ & & \\
\hline .223 & 3.23666 & -3.95465 & $\begin{array}{l}\text { Fourth } \\
\text { year }\end{array}$ & & \\
\hline .027 & 10.28944 & $22.86879 *$ & $\begin{array}{l}\text { First } \\
\text { year }\end{array}$ & \multirow{3}{*}{$\begin{array}{l}\text { Fourth } \\
\text { year }\end{array}$} & \\
\hline .046 & 4.37978 & $8.75904 *$ & $\begin{array}{l}\text { Second } \\
\text { year }\end{array}$ & & \\
\hline .223 & 3.23666 & 3.95465 & $\begin{array}{l}\text { Third } \\
\text { year }\end{array}$ & & \\
\hline
\end{tabular}

Table (9) indicates that there is a statistically significant difference in the degree of female students possessing soft experience from the point of view of the faculty members according to the variable of experience in the first, fifth and the total degree. 
TABLE IX. SHOWS THE RESUlts OF THE VARIANCE ANALYSIS FOR THE QUESTIONNAIRE ACCORDING TO THE VARIABLE OF EXPERIENCE

\begin{tabular}{|c|c|c|c|c|c|c|}
\hline $\begin{array}{l}\text { Leve } \\
\text { l }\end{array}$ & $\mathbf{F}$ & $\begin{array}{l}\text { Average } \\
\text { Squares }\end{array}$ & $\begin{array}{l}\text { Freedo } \\
\text { m } \\
\text { degree } \\
\text { Degree }\end{array}$ & $\begin{array}{l}\text { Total } \\
\text { Squares }\end{array}$ & $\begin{array}{l}\text { Source of } \\
\text { Contrast }\end{array}$ & $\begin{array}{l}\text { Dimensio } \\
\mathbf{n}\end{array}$ \\
\hline \multirow[t]{3}{*}{.012} & \multirow[t]{3}{*}{$\begin{array}{l}4.62 \\
5\end{array}$} & 69.624 & 3 & 208.872 & $\begin{array}{l}\text { Between } \\
\text { groups }\end{array}$ & \multirow{3}{*}{$\mathrm{d} 1$} \\
\hline & & \multirow[t]{2}{*}{15.053} & 22 & \multirow{2}{*}{$\begin{array}{l}331.167 \\
540.038\end{array}$} & In the groups & \\
\hline & & & 25 & & Total & \\
\hline \multirow[t]{3}{*}{.157} & \multirow[t]{3}{*}{$\begin{array}{l}1.91 \\
3\end{array}$} & \multirow{3}{*}{$\begin{array}{l}14.515 \\
7.587\end{array}$} & & \multirow{3}{*}{$\begin{array}{l}43.545 \\
166.917 \\
210.462\end{array}$} & $\begin{array}{l}\text { Between } \\
\text { groups }\end{array}$ & \multirow{3}{*}{$\mathrm{d} 2$} \\
\hline & & & 22 & & In the groups & \\
\hline & & & 25 & & Total & \\
\hline \multirow[t]{3}{*}{.515} & \multirow[t]{3}{*}{.786} & \multirow{3}{*}{$\begin{array}{l}14.038 \\
17.864\end{array}$} & & \multirow{3}{*}{$\begin{array}{l}42.115 \\
393.000 \\
435.115\end{array}$} & $\begin{array}{l}\text { Between } \\
\text { groups }\end{array}$ & \multirow{3}{*}{$\mathrm{d} 3$} \\
\hline & & & 22 & & In the groups & \\
\hline & & & 25 & & Total & \\
\hline \multirow[t]{3}{*}{.198} & \multirow[t]{3}{*}{$\begin{array}{l}1.68 \\
9\end{array}$} & \multirow{3}{*}{$\begin{array}{l}11.350 \\
6.720\end{array}$} & 3 & \multirow{3}{*}{$\begin{array}{l}34.051 \\
147.833 \\
181.885\end{array}$} & $\begin{array}{l}\text { Between } \\
\text { groups }\end{array}$ & \multirow{3}{*}{$\mathrm{d} 4$} \\
\hline & & & 22 & & In the groups & \\
\hline & & & 25 & & Total & \\
\hline \multirow[t]{3}{*}{.008} & \multirow[t]{3}{*}{$\begin{array}{l}5.06 \\
6\end{array}$} & \multirow{3}{*}{$\begin{array}{l}62.444 \\
12.326\end{array}$} & & \multirow{3}{*}{$\begin{array}{l}187.333 \\
271.167 \\
458.500\end{array}$} & $\begin{array}{l}\text { Between } \\
\text { groups }\end{array}$ & \multirow{3}{*}{ d5 } \\
\hline & & & 22 & & In the groups & \\
\hline & & & 25 & & Total & \\
\hline \multirow[t]{3}{*}{.548} & \multirow[t]{3}{*}{.725} & \multirow{3}{*}{$\begin{array}{l}7.600 \\
10.481\end{array}$} & 3 & \multirow{3}{*}{$\begin{array}{l}22.801 \\
230.583 \\
253.385\end{array}$} & $\begin{array}{l}\text { Between } \\
\text { groups }\end{array}$ & \multirow{3}{*}{ d6 } \\
\hline & & & 22 & & In the groups & \\
\hline & & & 25 & & Total & \\
\hline .063 & $\begin{array}{l}2.81 \\
9\end{array}$ & 61.628 & 3 & 184.885 & $\begin{array}{l}\text { Between } \\
\text { groups }\end{array}$ & \\
\hline & & 21.864 & 22 & 481.000 & In the groups & d7 \\
\hline & & & 25 & 665.885 & Total & \\
\hline .063 & $\begin{array}{l}2.81 \\
7\end{array}$ & 41.690 & 3 & & $\begin{array}{l}\text { Between } \\
\text { groups }\end{array}$ & \\
\hline & & 14.799 & 22 & 325.583 & In the groups & $\mathrm{d} 8$ \\
\hline & & & 25 & 450.654 & Total & \\
\hline .081 & $\begin{array}{l}2.56 \\
1\end{array}$ & 35.921 & 3 & 107.763 & $\begin{array}{l}\text { Between } \\
\text { groups }\end{array}$ & \\
\hline & & 14.027 & 22 & 308.583 & In the groups & d9 \\
\hline & & & 25 & 416.346 & Total & \\
\hline .023 & $\begin{array}{l}3.87 \\
2\end{array}$ & $\begin{array}{l}2004.59 \\
8\end{array}$ & 3 & 6013.795 & $\begin{array}{l}\text { Between } \\
\text { groups }\end{array}$ & \\
\hline & & 517.780 & 22 & 11391.167 & In the groups & \\
\hline & & & 25 & 17404.962 & Total & \\
\hline
\end{tabular}

TABLE X. ShOWS THE DIFFERENCE TRENDS. LSD (LEAST SigNIFICANT DIFFERENCES) WAS PERFORMED FOR THE REMOTE COMPARISONS

\begin{tabular}{|c|c|c|c|c|c|}
\hline $\begin{array}{l}\text { Varia } \\
\text { nce }\end{array}$ & $\begin{array}{l}\text { Standard } \\
\text { error }\end{array}$ & $\begin{array}{l}\text { Intermediate } \\
\text { Teams (I-J) }\end{array}$ & Experience $\mathbf{j}$ & $\begin{array}{l}\text { Experie } \\
\text { nce }\end{array}$ & $\begin{array}{l}\text { dimensi } \\
\text { on }\end{array}$ \\
\hline .150 & 1.82632 & 2.72727 & $\begin{array}{l}\text { From 4-8 } \\
\text { years }\end{array}$ & \multirow{3}{*}{$\begin{array}{l}\text { Less } \\
\text { than } 4 \\
\text { Years }\end{array}$} & \multirow{12}{*}{$\mathrm{d} 1$} \\
\hline .173 & 3.29245 & -4.63636 & 8-10 years & & \\
\hline .351 & 3.29245 & -3.13636 & $\begin{array}{l}\text { More than10 } \\
\text { years }\end{array}$ & & \\
\hline .150 & 1.82632 & -2.72727 & $\begin{array}{l}\text { Less than } 4 \\
\text { Years }\end{array}$ & \multirow{3}{*}{$\begin{array}{l}\text { Less } \\
\text { than4 } \\
\text { Years }\end{array}$} & \\
\hline .036 & 3.29245 & $-7.36364 *$ & $8-10$ & & \\
\hline .089 & 3.29245 & -5.86364 & $\begin{array}{l}\text { More than } 10 \\
\text { years }\end{array}$ & & \\
\hline .173 & 3.29245 & 4.63636 & Less than 4 & \multirow{3}{*}{$8-10$} & \\
\hline .036 & 3.29245 & 7.36364* & $4-8$ & & \\
\hline .730 & 4.28311 & 1.50000 & $\begin{array}{l}\text { More than } 10 \\
\text { year }\end{array}$ & & \\
\hline .351 & 3.29245 & 3.13636 & $\begin{array}{l}\text { Less than } \\
4 \text { years }\end{array}$ & \multirow{3}{*}{$\begin{array}{l}\text { More } \\
\text { than } 10\end{array}$} & \\
\hline .089 & 3.29245 & 5.86364 & $4-8$ & & \\
\hline .730 & 4.28311 & -1.50000 & $8-10$ & & \\
\hline .295 & 1.52453 & 1.63636 & $4-8$ & \multirow{3}{*}{$\begin{array}{l}\text { Less } \\
\text { than } \\
4 \text { years }\end{array}$} & \multirow{24}{*}{ d5 } \\
\hline .015 & 2.74839 & $-7.22727^{*}$ & $8-10$ & & \\
\hline .099 & 2.74839 & -4.72727 & $\begin{array}{l}\text { Imore than } \\
10 \text { years }\end{array}$ & & \\
\hline .295 & 1.52453 & -1.63636 & $\begin{array}{l}\text { Less than } \\
4 \text { year } \\
\end{array}$ & \multirow{3}{*}{ 4- 8} & \\
\hline .004 & 2.74839 & $-8.86364 *$ & $8-10$ & & \\
\hline .030 & 2.74839 & $-6.36364 *$ & $\begin{array}{l}\text { More than } \\
10 \text { years }\end{array}$ & & \\
\hline .015 & 2.74839 & $7.22727^{*}$ & $\begin{array}{l}\text { Less than } \\
4 \text { years }\end{array}$ & \multirow{3}{*}{$8-10$} & \\
\hline .004 & 2.74839 & $8.86364 *$ & $4-8$ & & \\
\hline .492 & 3.57534 & 2.50000 & $\begin{array}{l}\text { More than } 10 \\
\text { years }\end{array}$ & & \\
\hline .099 & 2.74839 & 4.72727 & $\begin{array}{l}\text { Less than } \\
4 \text { years }\end{array}$ & \multirow{3}{*}{$\begin{array}{l}\text { More } \\
\text { than } \\
10 \text { years }\end{array}$} & \\
\hline .030 & 2.74839 & $6.36364 *$ & 4- 8 & & \\
\hline .492 & 3.57534 & -2.50000 & $8-10$ & & \\
\hline .055 & 9.36817 & 19.00000 & $4-8$ & \multirow{3}{*}{$\begin{array}{l}\text { Less } \\
\text { than } \\
4 \text { years }\end{array}$} & \\
\hline .062 & 16.88871 & -33.18182 & $8-10$ & & \\
\hline .203 & 16.88871 & -22.18182 & $\begin{array}{l}\text { More than } 10 \\
\text { years }\end{array}$ & & \\
\hline .055 & 9.36817 & -19.00000 & $\begin{array}{l}\text { Less than } \\
4 \text { years }\end{array}$ & \multirow{3}{*}{ 4- 8} & \\
\hline .005 & 16.88871 & $-52.18182^{*}$ & $8-10$ & & \\
\hline .023 & 16.88871 & $-41.18182^{*}$ & $\begin{array}{l}\text { More than } \\
10 \text { years }\end{array}$ & & \\
\hline .062 & 16.88871 & 33.18182 & $\begin{array}{l}\text { Less than } 4 \\
\text { years }\end{array}$ & \multirow{3}{*}{$8-10$} & \\
\hline .005 & 16.88871 & $52.18182 *$ & 4- 8 & & \\
\hline .622 & 21.97030 & 11.00000 & $\begin{array}{l}\text { More than } \\
10 \text { years }\end{array}$ & & \\
\hline .203 & 16.88871 & 22.18182 & $\begin{array}{l}\text { Less than } \\
4 \text { years }\end{array}$ & \multirow{3}{*}{$\begin{array}{l}\text { More } \\
\text { than } 10 \\
\text { years }\end{array}$} & \\
\hline .023 & 16.88871 & $41.18182 *$ & 4- 8 & & \\
\hline .622 & 21.97030 & -11.00000 & $8-10$ & & \\
\hline
\end{tabular}

It is noted in Table (10) that the difference in the comparisons for the benefit of the higher experience. To find out if there is a statistically significant difference in the degree of faculty members' assessment of soft skills due to the specialization variable. 
TABLE XI. ANALYSIS OF VARIANCE OF THE QUESTIONNAIRE ACCORDING TO THE SPECIALIZATION VARIABLE

\begin{tabular}{|c|c|c|c|c|c|c|}
\hline $\begin{array}{l}\text { Level of } \\
\text { significanc } \\
\mathrm{e}\end{array}$ & $\mathbf{F}$ & $\begin{array}{l}\text { Average } \\
\text { squares }\end{array}$ & $\begin{array}{l}\text { Degree } \\
\text { of } \\
\text { freedo } \\
\mathbf{m} \\
\end{array}$ & $\begin{array}{l}\text { Total } \\
\text { squares }\end{array}$ & $\begin{array}{l}\text { Source of } \\
\text { Contrast }\end{array}$ & d \\
\hline \multirow[t]{3}{*}{.458} & .808 & 17.726 & 2 & 35.453 & Between groups & \multirow{3}{*}{ d1 } \\
\hline & & 21.939 & 23 & 504.586 & In the groups & \\
\hline & & & 25 & 540.038 & Total & \\
\hline \multirow[t]{3}{*}{.268} & $\begin{array}{l}1.39 \\
4\end{array}$ & 11.374 & 2 & 22.747 & Between groups & \multirow{3}{*}{$\mathrm{d} 2$} \\
\hline & & 8.161 & 23 & 187.714 & In the groups & \\
\hline & & & 25 & 210.462 & Total & \\
\hline \multirow[t]{3}{*}{.580} & .558 & 10.065 & 2 & 20.130 & Between groups & \multirow{3}{*}{$\mathrm{d} 3$} \\
\hline & & 18.043 & 23 & 414.986 & In the groups & \\
\hline & & & 25 & 435.115 & Total & \\
\hline \multirow[t]{3}{*}{.480} & .758 & 5.621 & 2 & 11.242 & Between groups & \multirow{3}{*}{$\mathrm{d} 4$} \\
\hline & & 7.419 & 23 & 170.643 & In the groups & \\
\hline & & & 25 & 181.885 & Total & \\
\hline \multirow[t]{3}{*}{.351} & $\begin{array}{l}1.09 \\
5\end{array}$ & 19.929 & 2 & 39.857 & Between groups & \multirow{3}{*}{ d5 } \\
\hline & & 18.202 & 23 & 418.643 & In the groups & \\
\hline & & & 25 & 458.500 & Total & \\
\hline \multirow[t]{3}{*}{.624} & .481 & 5.085 & 2 & 10.170 & Between groups & \multirow{3}{*}{ d6 } \\
\hline & & 10.575 & 23 & 243.214 & In the groups & \\
\hline & & & 25 & 253.385 & Total & \\
\hline \multirow[t]{3}{*}{.307} & $\begin{array}{l}1.24 \\
5\end{array}$ & 32.514 & 2 & 65.027 & Between groups & \multirow{3}{*}{ d7 } \\
\hline & & 26.124 & 23 & 600.857 & In the groups & \\
\hline & & & 25 & 665.885 & Total & \\
\hline \multirow[t]{3}{*}{.756} & .283 & 5.405 & 2 & 10.811 & Between groups & \multirow{3}{*}{$\mathrm{d} 8$} \\
\hline & & 19.124 & 23 & 439.843 & In the groups & \\
\hline & & & 25 & 450.654 & Total & \\
\hline \multirow[t]{3}{*}{.103} & $\begin{array}{l}2.51 \\
1\end{array}$ & 37.309 & 2 & 74.618 & Between groups & \multirow{3}{*}{ d9 } \\
\hline & & 14.858 & 23 & 341.729 & In the groups & \\
\hline & & & 25 & 416.346 & Total & \\
\hline \multirow[t]{3}{*}{.399} & .956 & $\begin{array}{l}667.61 \\
6\end{array}$ & 2 & 1335.233 & Between groups & \multirow{3}{*}{$\begin{array}{l}\text { Tota } \\
1\end{array}$} \\
\hline & & $\begin{array}{l}698.68 \\
4\end{array}$ & 23 & $\begin{array}{l}16069.72 \\
9\end{array}$ & In the groups & \\
\hline & & & 25 & $\begin{array}{l}17404.96 \\
2\end{array}$ & Total & \\
\hline
\end{tabular}

Table (11) indicates that there are no statistically significant differences in the degree of female faculty members' assessment of soft skills due to specialization variable.

\section{DISCUSSION OF RESULTS}

It should be noted here that most of the previous studies that were reviewed examined soft skills in terms of their impact on post-graduate employment, and how the lack of these skills among university graduates prevents them from getting the jobs they want in the face of great competition among graduates from The findings of our current study indicate that the female students of the special education department at Princess Nora University from their point of view and the view of the faculty members were low on the dimensions of the nine scale. This result is consistent with the results of the [8] The study also noted the need to raise awareness about the importance of soft skills and encourage students to improve their soft skills. Our current study is similar in its results with the study of [9], which noted that the importance of training students and professionals in soft skills, And personal skills, where the sample of the study indicated that the possession of skills increases the imposition of employment and competition for jobs, and the current study alerted to the importance of possessing soft skills, where the study of pilgrims (2014) to the existence of statistical significance between the capture of administrative functions and variable Will reduce the soft skills, and recommended the study of job seekers need to develop their soft skills and refined and gain the missing.

As the loss of these skills reduces their access to administrative work as the study showed, and the results of the study show that students in the Department of Special Education lack soft skills in sufficient form, and with regard to the study of Shaheen and his colleagues [10], which noted that business students in general in Singapore were aware of the importance of soft skills for work and career advancement, and that soft skills contribute greatly to their academic performance. The results of this study are one of the objectives of the current study The study recommended the need to raise awareness of the importance of these skills, and intersect the results of this study with the results of our current study, which showed that the soft skills of students are low and this [13] has shown that $60 \%$ of employers do not employ university graduates and most job applicants due to their lack of soft skills, so believe The researchers said that it is appropriate to pay attention to the results of the current study and the necessary work with regard to the inclusion in the various university courses of soft skills required, and include them in various university activities, and awareness of the importance of availability of university students [4].

\section{RECOMMENDATIONS}

In the light of the findings of the researchers, they suggest the following:

- Educating students about the importance of soft skills and the need to possess these skills in order to achieve success in practical life. 
- More attention is paid to soft skills by faculty members, by including courses in various activities that focus on these skills.

- Conduct other studies on other samples of female students, so that the samples are larger, and the disciplines are different.

- Provide various activities through student clubs, through which workshops and courses and lectures on soft skills in different dimensions, to contribute to shaping the character of the student better.

- The researchers also recommend conducting follow-up studies on female graduates in particular, and the university in general, to find out the impact of the availability of soft skills or not on the chances of employment and success in their various jobs.

\section{REFERENCES}

[1] Al-Jamri, Mansour (2015). Soft skills, article published in the newspaper Al-Wasat, No. 4598, Friday 10 April 2015 corresponding to 20 Jumada II $1436 \mathrm{AH}$

[2] Hajjaj, Ola (2014). The role of soft skills in the process of capturing administrative positions, applied case study on administrative jobs in the Gaza Strip, Master Thesis, Faculty of Commerce, Islamic University, Gaza.

[3] Khamis, Abdullah (2013) Soft skills they are looking for, Vision Foundation for Press and Publishing, Amman, Jordan
[4] Saeed, Omar (2011). Principles of evaluation and classification of the universities of the Islamic world, a vision of originality, Sudan, African International University

[5] Sweilem, Faiza (2013). Soft Skills Personal qualities put their owners at the forefront of the recruitment marathon, "Vision Foundation for Press and Publishing, Amman, Jordan.

[6] Chalabi, Nawal (2014). Proposed Framework for Integrating 21st Century Skills into Science Curricula in Basic Education in Egypt, Specialized International Journal of Education, No. 10, 3.

[7] Arfaj, Maher (2-14). Soft Skills, an introduction to the College of Education, King Faisal University, Dammam, Saudi Arabia.

[8] Schulz, B. (2008). The Important of Soft Skills: Education Beyond Academic Knowledge. NAWA Journal of Language and Communication Polytechnic of Namibia.

[9] Seetha, S, (2013). Necessity of Soft Skills Training for Stu dents and Professionals. 4(2) March- may, 2013, pp. 171-174. India: International Journal of Engineering, Business and Enterprise Applications.

[10] Shaheen, M, Zhang, L, Shen, T,\& Siti, (2012). Impotence of Soft for Education and Career Success, Volume 2, Issue 2. Nanyang Technological University, Singapore, International Journal for Cros disciplinary Subject in Education ( IJCDSE), special.

[11] Tobin, p. (2006). Managing ourselves leadership: Experiential Leadership: Experiential learning and leadership Development. Vol.12, pp36-42. Journal, Barthay, Ambleside.

[12] Vijayalakshmi, V. (2016). Soft Skills- The Need of the Hour for Professional competence : A Review on Interpersonal skills and Theories. Volume. 11, Number 4, pp. 2859-2864. International Journal of Applied Engineering Reseaech.

[13] White, Martha (2012). "The Real New College Grads Can't Get Hired". 